Article

\title{
Irrigation with Wastewater and K Fertilization Ensure the Yield and Quality of Coloured Cotton in a Semiarid Climate
}

\author{
Breno Leonan de Carvalho Lima ${ }^{1, *(1)}$, Ênio Farias de França e Silva ${ }^{2} \mathbb{1}$, João Henrique Zonta ${ }^{3}$, \\ Cícero Pereira Cordão Terceiro Neto ${ }^{4}$, Claudivan Feitosa de Lacerda ${ }^{5}{ }^{(0)}$, Jorge Freire da Silva Ferreira ${ }^{6, *}$ \\ and Flávio José Rodrigues $\mathrm{Cruz}^{7}$
}

check for updates

Citation: Lima, B.L.C.; Silva, Ê.F.F. Zonta, J.H.; Cordão Terceiro Neto, C.P.; Lacerda, C.F.; Ferreira, J.F.S.; Cruz, F.J.R. Irrigation with Wastewater and K Fertilization Ensure the Yield and Quality of Coloured Cotton in a Semiarid Climate. Agronomy 2021, 11, 2370. https://doi.org/10.3390/ agronomy 11122370

Academic Editor: Alejandro Galindo

Received: 20 October 2021

Accepted: 22 November 2021

Published: 23 November 2021

Publisher's Note: MDPI stays neutral with regard to jurisdictional claims in published maps and institutional affiliations.

Copyright: (c) 2021 by the authors. Licensee MDPI, Basel, Switzerland. This article is an open access article distributed under the terms and conditions of the Creative Commons Attribution (CC BY) license (https:// creativecommons.org/licenses/by/ $4.0 /)$.
1 Water Resources Core, National Institute of the Semi-Arid, Campina Grande 58434-700, PB, Brazil

2 Department of Agricultural Engineering, Federal Rural University of Pernambuco, Recife 52171-900, PE, Brazil; enio.fsilva@ufrpe.br

3 National Cotton Research Center, Brazilian Agricultural Research Corporation, Campina Grande 58428-095, PB, Brazil; joao-henrique.zonta@embrapa.br

4 Research, Rural Extension and Land Regularization Paraíba Company, Cabedelo 58108-502, PB, Brazil; cicerocordao@yahoo.com.br

5 Department of Agricultural Engineering, Federal University of Ceará, Fortaleza 60450-760, CE, Brazil; cfeitosa@ufc.br

6 United States Salinity Laboratory USDA-ARS, Agricultural Water Efficiency and Salinity Research Unit, Riverside, CA 92507, USA

7 Federal Institute of Education, Science and Technology of Amapá, Laranjal do Jari 68920-000, AP, Brazil; fjrc@bol.com.br

* Correspondence: breno.lclima@gmail.com (B.L.C.L.); jorge.ferreira@usda.gov (J.F.S.F.)

Abstract: Treated domestic sewage (TDS) can contribute to plant nutrition and improve crop production. However, there are no data for its use in coloured cotton under a deficit or excess irrigation in combination with potassium fertilization rates (KRs), mainly under semiarid tropical conditions. The research was conducted using a randomized complete block design in a factorial scheme $(5 \times 5$, irrigation regimes vs. potassium rates), plus an additional treatment as the control $((5 \times 5)$ $+1)$. The treatments consisted of five TDS irrigation regimes $(50,75,100,125$, and 150\% of crop evapotranspiration-ETc) and five KRs (0,50,100, 150, and 200\% of the local crop recommendation), plus a control-CT - (irrigated with fresh water at 100\% ETc and fertilized according to the local crop recommendation) and four replications. The optimal crop yield, water use efficiency, and potassium use efficiency were obtained when TDS was applied as a deficit irrigation treatment of $75 \%$ of ETc or as full irrigation (100\% of ETc) and when associated with moderate increases in K fertilization. These treatments also resulted in a better fibre quality when compared to the $\mathrm{CT}$, meeting or exceeding the requirements of the textile industry. Therefore, moderate deficit irrigation with TDS is indicated as an important strategy to save fresh water and to reduce the use of fertilizers, while having the potential to increase profit margins for cotton production in tropical semiarid regions.

Keywords: Gossypium hirsutum L.; textile industry; domestic sewage; recycled water; water use efficiency

\section{Introduction}

Cotton (Gossypium hirsutum L.) is the most important natural fibre in the world, constituting the main raw material for the international textile industry [1-3]. Currently, cotton is cultivated in more than 80 countries and the world consumption of lint exceeds 24 million tons, with China ranking as the major producer, followed by India, the United States, Pakistan, and Brazil [4].

The current modernization of the textile industries includes new spinning technologies and the production of new fibres, which must meet the technical standards that require long, uniform, mature, thin, and resistant fibres [5]. In this context, the cultivation of 
cotton cultivars with naturally coloured fibres has been gaining prominence in the Brazilian agricultural sector [6], especially due to the environmentally benign nature of its cultivation. Coloured cotton does not require any type of chemical dyeing and prevents the use of additional water that would be required for the conventional fabric dyeing process [6,7]. Additionally, coloured fibre varieties are resistant to drought and may improve the income of small farmers, who have few crop options that can grow under a semiarid tropical climate $[8,9]$.

Cotton provides the raw material for $40 \%$ of the clothing industry and is the third largest global consumer of irrigation water, requiring approximately $2700 \mathrm{~L}$ of water to produce cotton fibres for one shirt [10] and almost 10,000 L of water to produce $1.0 \mathrm{~kg}$ of cotton fabric [11] or $8000 \mathrm{~L}$ for a pair of cotton jeans. These circumstances led fabric manufacturers to adopt alternative and environmentally sustainable production technologies to minimize the use of water resources and reduce environmental pollution [12]. Recently, the possibility of reusing wastewater for the irrigation of high water-demanding crops, such as cotton, was evaluated as a viable alternative to preserve natural water resources, while mitigating the effects of water shortage [13] and climate change. Recurring droughts in semiarid regions of the planet and the excessive pumping of groundwater to meet water demands for irrigated agriculture are leading to the drying of millions of wells world-

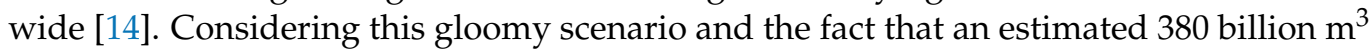
of wastewater are produced annually worldwide [15], these authors highlight the value of wastewater as a rich source of the macronutrients $\mathrm{N}, \mathrm{P}$, and $\mathrm{K}$, and as an alternative to mitigate the water scarcity on Earth.

Wastewater use allows for the recycling of nutrients such as $\mathrm{N}, \mathrm{P}$, and $\mathrm{K}$, leading to the reduced use of chemical fertilizers $[15,16]$. However, the total of nutrients supplied by the wastewater may not be enough to meet the crop demand in terms of high productivity and quality. For example, some reports state that irrigation with wastewaters and $\mathrm{K}$ fertilization improves the quality of white-cotton fibre [17-20]. However, there is no evidence of these beneficial effects for coloured cotton cultivars. Therefore, this study explores the interaction between the agricultural use of treated domestic sewage, irrigation regimes, and $\mathrm{K}$ rates on a cultivar of coloured cotton grown under a semiarid tropical climate. The objectives of this work are to find the management that results in greater seed cotton productivity, higher boll density, better fibre quality, and higher water use efficiency.

\section{Materials and Methods}

\subsection{Study Area Location and Characteristics}

The study was carried out from 15 April to 30 August 2016 in a semiarid tropical region located at the Hydro-Agricultural Reuse Pilot Unit of the Agricultural Engineering Department of the Federal Rural University of Pernambuco in Ibimirim, Brazil $\left(8^{\circ} 32^{\prime} 05^{\prime \prime} \mathrm{S}\right.$; $37^{\circ} 41^{\prime} 50^{\prime \prime} \mathrm{W}$; average altitude of $408 \mathrm{~m}$ ) (Figure $1 \mathrm{a}-\mathrm{c}$ ).

The climate of the region is classified as BSh (hot semiarid climate) according to Köppen's classification adapted to Brazil [21], with an average annual precipitation of $454 \mathrm{~mm}$. During the 4.5-month experimental period, the accumulated precipitation was $122 \mathrm{~mm}$, with average air temperature and relative humidity of $24.6^{\circ} \mathrm{C}$ and $63 \%$, respectively, with approximately $80 \%$ of the precipitation occurring in May (Figure 2).

The experiment was set up in an Arenosol (Entisol Quartzipsamments) [22] of sandyloam texture, with 760, 80, and $160 \mathrm{~g} \mathrm{~kg}^{-1}$ of sand, silt, and clay, respectively. The soil had the following chemical characteristics: (at 0-20 cm), $\mathrm{pH}=4.6, \mathrm{P}=25 \mathrm{mg} \mathrm{dm}^{-3}$, and (in $\left.\mathrm{cmol}_{\mathrm{C}} \mathrm{dm}^{-3}\right): 1.25\left(\mathrm{Ca}^{2+}\right), 0.75\left(\mathrm{Mg}^{2+}\right), 0.03\left(\mathrm{Na}^{+}\right), 0.19\left(\mathrm{~K}^{+}\right), 0.15\left(\mathrm{Al}^{3+}\right)$, and $1.56\left(\mathrm{H}^{+}\right.$ $\left.+\mathrm{Al}^{3+}\right) ;($ at $20-40 \mathrm{~cm}), \mathrm{pH}=4.3, \mathrm{P}=19 \mathrm{mg} \mathrm{dm}^{-3}$, and $\left(\right.$ in $\left.\mathrm{cmol}_{\mathrm{C}} \mathrm{dm}^{-3}\right): 1.40\left(\mathrm{Ca}^{2+}\right)$, $0.70\left(\mathrm{Mg}^{2+}\right), 0.04\left(\mathrm{Na}^{+}\right), 0.24\left(\mathrm{~K}^{+}\right)$or $187 \mathrm{~kg} \mathrm{ha}{ }^{-1}, 0.40\left(\mathrm{Al}^{3+}\right), 2.14\left(\mathrm{H}^{+}+\mathrm{Al}^{3+}\right)$. Further information on soil analysis was published elsewhere [23]. 

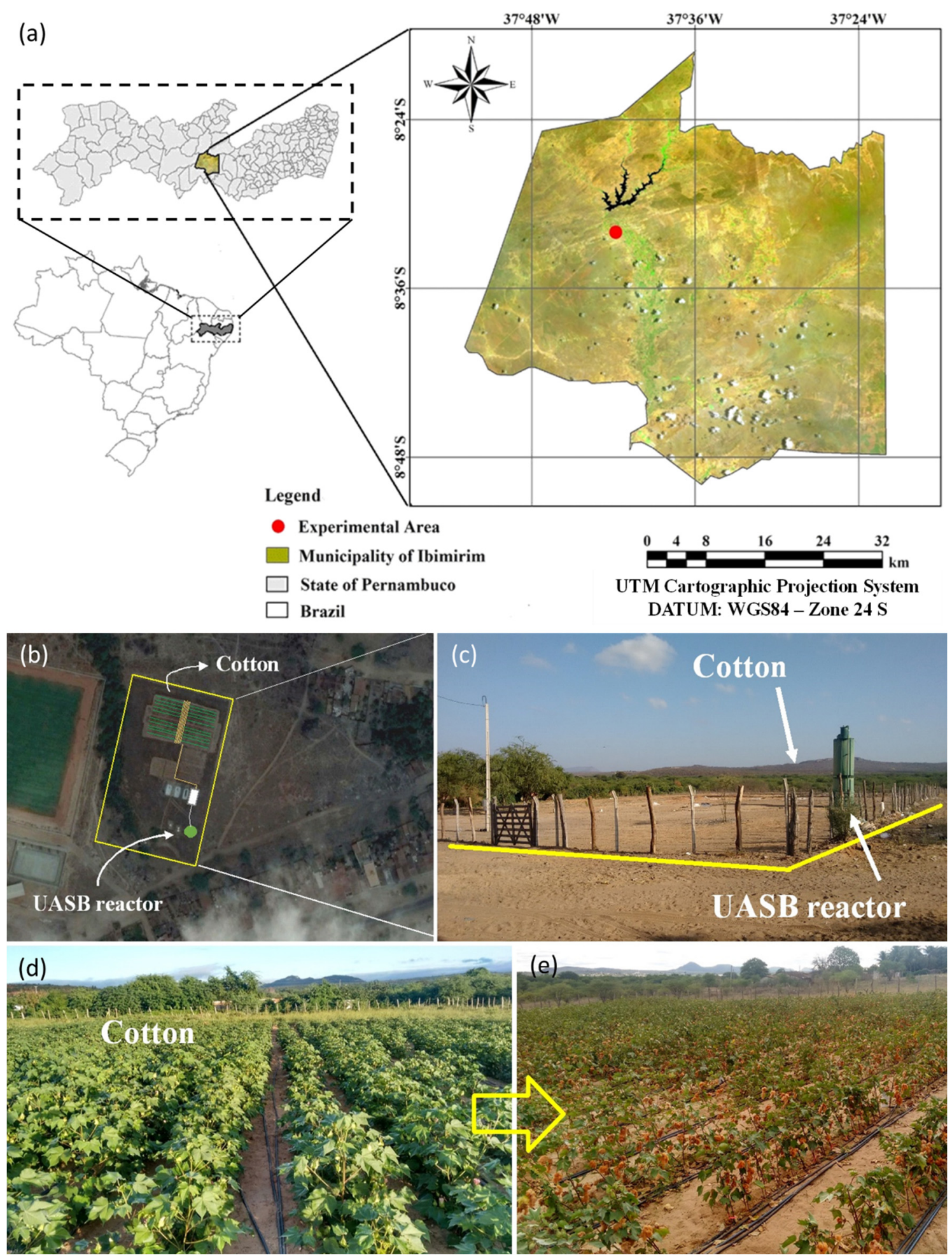

Figure 1. Study area located in Ibimirim, state of Pernambuco, Brazil (a), Hydro-Agricultural Reuse Pilot Unit (b), front view of Hydro-Agricultural Reuse Pilot Unit (c), cotton plants at development stage II-flower buds; (d) cotton plants at development stage IV-boll maturation (e). UASB = Upflow Anaerobic Sludge Blanket; UTM = Universal Transverse Mercator coordinate system.

\subsection{Experimental Design and Treatments}

The study was carried out in a Randomized Complete Block Design (RCBD), in a factorial arrangement plus a control treatment $[(5 \times 5)+1]$ with four replications, totalling 
104 experimental plots. The treatments consisted of five irrigation regimes (IR) $(50,75,100$, 125 , and $150 \%$ of crop evapotranspiration $\left(E T_{C}\right)$ ), using treated domestic sewage (TDS), five $\mathrm{K}$ rates (KRs) corresponding to $0,50,100,150$, and $200 \%$ of the local crop recommendation, and an additional control treatment (CT) consisting of freshwater from a tubular well at $100 \% E T_{C}$ (equivalent to $100 \mathrm{IR}$ ) and fertilized according to the local crop recommendation (equivalent to $100 \mathrm{KR})$.

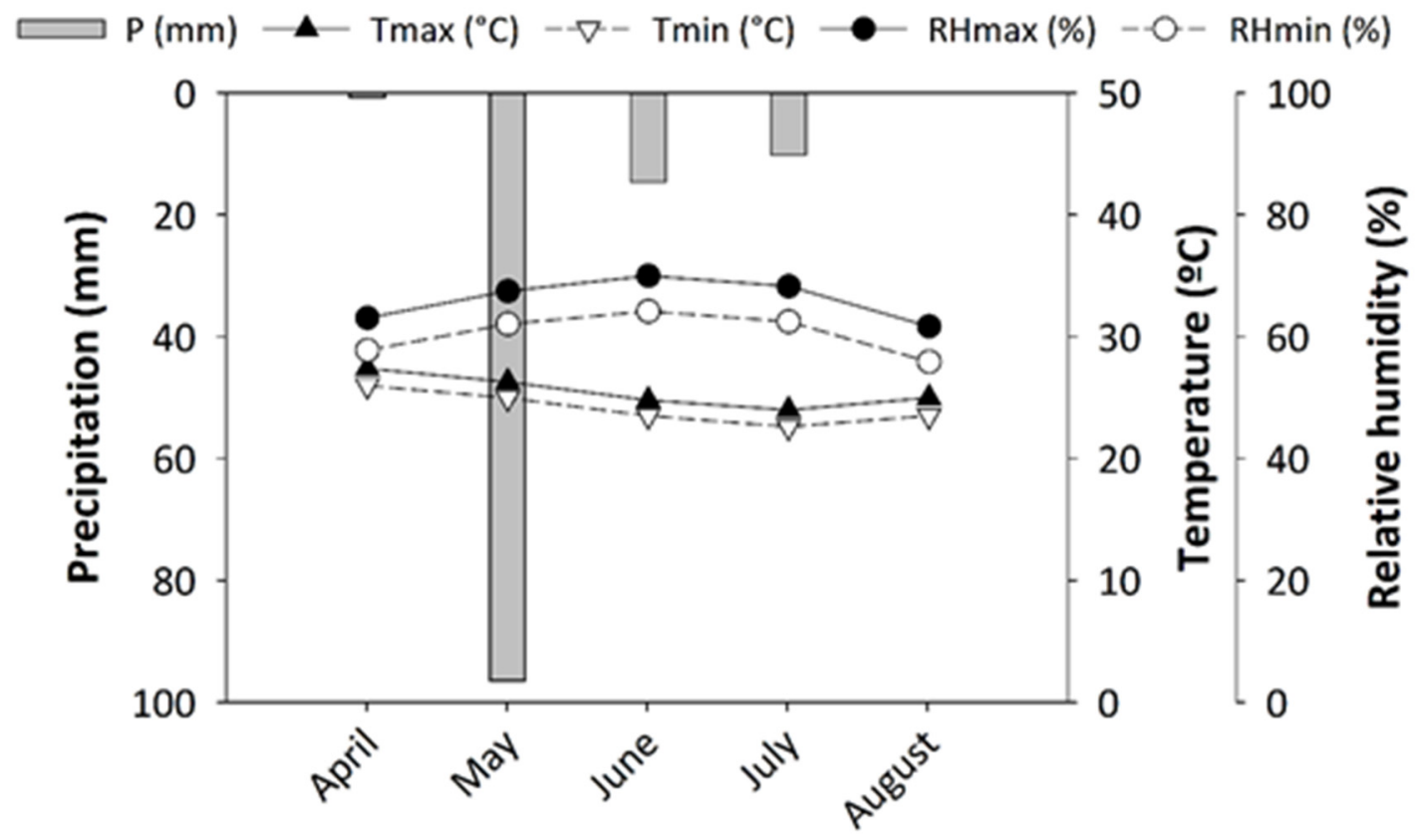

Month

Figure 2. Maximum $(\bullet)$ and minimum $(\circ)$ relative humidity $(\%)$, maximum $(\boldsymbol{\Delta})$ and minimum $(\Delta)$ air temperature $\left({ }^{\circ} \mathrm{C}\right)$, and monthly precipitation $(\mathrm{mm})$ during the experimental period in Ibimirim, Brazil, 2016.

\subsection{Plant Material and Planting Conditions}

The genetic material used was the cotton (Gossypium hirsutum L.) cultivar BRS Rubi, recommended for cultivation in the semiarid region of northeastern Brazil, with browndark-coloured fibre, cycle ranging from 120 to 140 days and tolerance to drought. Sowing was initially performed using 25 seeds per meter, leaving 10 plants per linear meter after thinning. The experimental plot was $15.0 \mathrm{~m}^{2}$, consisting of three single rows of cotton $5.0 \mathrm{~m}$ long and spaced by $1.0 \mathrm{~m}$. The useful area of the plot comprised the central row, disregarding $0.5 \mathrm{~m}$ on each side.

\subsection{Water Source Characterization and Irrigation Management}

Treated domestic sewage (TDS), processed by a UASB (Upflow Anaerobic Sludge Blanket) reactor, had average concentrations of 3.74, 1.73, 5.78, 4.82, 2.0, and $1.12 \mathrm{mmol}_{\mathrm{C}} \mathrm{L}^{-1}$ for $\mathrm{Ca}^{2+}, \mathrm{Mg}^{2+}, \mathrm{Na}^{+}, \mathrm{Cl}^{-}, \mathrm{NO}_{3}{ }^{-}$, and $\mathrm{K}^{+}$, respectively, with an electrical conductivity $\left(\mathrm{EC}_{\mathrm{W}}\right)$ of $2.1 \mathrm{dS} \mathrm{m}^{-1}$ and $\mathrm{pH}=7.2$, while freshwater from a municipal tubular well (Ibimirim, Pernambuco, Brazil) with a depth of $105 \mathrm{~m}$ and a flow rate of $35 \mathrm{~m}^{3} \mathrm{~h}^{-1}$ had concentrations of $2.72,0.36,0.82,0.91,0.0$, and $0.27 \mathrm{mmol}_{\mathrm{C}} \mathrm{L}^{-1}$ for $\mathrm{Ca}^{2+}, \mathrm{Mg}^{2+}, \mathrm{Na}^{+}, \mathrm{Cl}^{-}, \mathrm{NO}_{3}{ }^{-}$, and $\mathrm{K}^{+}$, respectively, with an $\mathrm{EC}_{\mathrm{w}}$ of $0.3 \mathrm{dS} \mathrm{m}^{-1}$ and $\mathrm{pH}=6.6$ [23]. The methodology for analysing water sources used in this study followed the recommendations of the Standard Methods for Examination of Water and Wastewater [24].

Irrigation management was carried out by adopting a daily irrigation shift and crop evapotranspiration was calculated according to the methodology proposed by [25] (Equation (1)), with daily reference evapotranspiration $\left(E T_{0}\right)$ estimated by the Penman- 
Monteith model (Equation (2)) and crop coefficient $\left(K_{C}\right)$ proposed by [26] (Equation (3)). The location coefficient $\left(K_{L}\right)$ was used to correct the $E T_{C}$ and was determined along with the development of the cotton crop using the methodology proposed by [27] (Equation (4)). The climatic data for $E T_{0}$ determination were obtained from an automated meteorological station (Campbell Scientific, CR1000 model, Logan, UT, USA) installed close to the experimental area.

$$
E T_{C}=E T_{0} K_{C} K_{L}
$$

$E T_{C}$ represents crop evapotranspiration $\left(\mathrm{mm} \mathrm{day}^{-1}\right), E T_{0}$ is the reference evapotranspiration $\left(\mathrm{mm} \mathrm{day}^{-1}\right), K_{C}$ is the crop coefficient (dimensionless), and $K_{L}$ is the location coefficient (dimensionless).

$$
\left.E T_{0}=\left[0.408(R n-G)+\gamma\left(900 /\left(T_{2}+273\right)\right) \mathrm{u}_{2}\left(\mathrm{e}_{\mathrm{s}}-\mathrm{e}_{\mathrm{a}}\right)\right)\right] /\left[\Delta+\gamma\left(1+0.34 \mathrm{u}_{2}\right)\right]
$$

$E T_{0}$ represents the reference evapotranspiration $\left(\mathrm{mm} \mathrm{day}^{-1}\right), R n$ is the net radiation on crop surface $\left(\mathrm{MJ} \mathrm{m}^{-2}\right.$ day $\left.^{-1}\right), G$ is the heat flux density of the soil $\left(\mathrm{MJ} \mathrm{m}^{-2}\right.$ day $\left.^{-1}\right), T_{2}$ is the air temperature at $2 \mathrm{~m}$ height $\left({ }^{\circ} \mathrm{C}\right), \mathrm{u}_{2}$ is the wind speed at $2 \mathrm{~m}$ height $\left(\mathrm{m} \mathrm{s}^{-1}\right), \mathrm{e}_{\mathrm{s}}$ is the saturation vapor pressure $(\mathrm{KPa}), \mathrm{e}_{\mathrm{a}}$ is the actual vapor pressure $(\mathrm{KPa}), \mathrm{e}_{\mathrm{s}}-\mathrm{e}_{\mathrm{a}}$ is the vapor pressure deficit $(\mathrm{KPa}), \Delta$ is the tangent to the vapor pressure curve $\left(\mathrm{KPa}^{\circ} \mathrm{C}^{-1}\right)$, and $\gamma$ is the psychrometric constant $\left(\mathrm{KPa}{ }^{\circ} \mathrm{C}^{-1}\right)$.

$$
K_{C}=0.632+0.009 \mathrm{DAE}-0.00006 \mathrm{DAE}^{2}
$$

In Equation (3), $K_{C}$ represents the daily crop coefficient (dimensionless) and DAE represents the number of days after the emergence of coloured cotton plants.

$$
K_{L}=0.10 \sqrt{ } P A S
$$

In Equation (4), $K_{L}$ represents the location coefficient (dimensionless) and PAS represents the percentage of area shaded by the crop (\%). PAS was calculated as a function of the shaded area (S) and crop spacing (Equation (5)), in which $S$ represents the projection of the shaded area for cotton at noon $\left(\mathrm{m}^{2}\right), E_{P}$ represents the spacing between plants $(\mathrm{m})$ and $E_{L}$ represents the spacing between lateral lines $(\mathrm{m})$.

$$
P A S=\left(S / E_{P} E_{L}\right) 100
$$

The cycle and duration of each phenological stage during the development of coloured cotton are described in Table 1. Irrigation with TDS was applied using a drip system, with lateral lines containing pressure-compensated drip tapes (DripNet PC 16250, Netafim, Tel Aviv, Israel) with a nominal diameter of $16 \mathrm{~mm}$, and drippers spaced by $0.30 \mathrm{~m}$ with a flow rate of $2.0 \mathrm{~L} \mathrm{~h}^{-1}$. A 735.5-W horizontal centrifugal pump (Schneider, Rueil-Malmaison, France) was used for effluent suction. Irrigation depths with treated domestic sewage were applied as a function of the irrigation time (Ti) (Equation (6)), adopting a daily interval.

$$
\left.\mathrm{Ti}=\left[(F)\left(E T_{C}\right)\left(E_{L} E_{D}\right)\right] /\left(q_{d} E_{a}\right)\right] 60
$$

In Equation (6), Ti represents the irrigation time (minutes), $F$ is the correction factor for the irrigation regime $\left(0.50,0.75,1.00,1.25\right.$, and 1.50 for $50,75,100,125$, and $150 \% E T_{C}$, respectively), $E T_{C}$ is crop evapotranspiration $\left(\mathrm{mm} \mathrm{day}^{-1}\right), E_{L}$ is the spacing between lateral lines $(\mathrm{m}), E_{D}$ is the spacing between drippers on the lateral line $(\mathrm{m}), q_{d}$ is the dripper flow rate $\left(\mathrm{L} \mathrm{h}^{-1}\right)$, and $E_{a}$ is the irrigation system efficiency $(\%)$.

At the end of the experiment, $135 \mathrm{DAE}$, the accumulated irrigation depths with treated domestic sewage corresponded to 307.8, 461.6, 615.5, 769.4, and $923.2 \mathrm{~mm}$ for 50, 75, 100, 125 , and $150 \% E T_{C}$, respectively. For the control treatment, the accumulated depth was $615.5 \mathrm{~mm}$. 
Table 1. The phenological cycle of coloured cotton, cv. 'BRS Rubi', observed during the experimental period. The developmental stages were based on field observations. DAE-days after seed emergence.

\begin{tabular}{cccc}
\hline Phase & Developmental Stages & DAE (Days) & Duration (Days) \\
\hline I & $\begin{array}{c}\text { Seed emergence up to 10\% of soil cover } \\
\text { 10\% of soil cover up to onset of } \\
\text { flowering }\end{array}$ & $1-19$ & 19 \\
II & Onset of flowering to the onset of boll & $20-41$ & 22 \\
& maturation & $42-89$ & 48 \\
III & Onset to end of boll maturation & $90-135$ & 46 \\
IV & Total cycle & 135 \\
\hline
\end{tabular}

\subsection{Liming and Fertilization}

The experimental soil had average (0-20 and 20-40 cm of depth) concentrations (in $\mathrm{cmol}_{\mathrm{C}} \mathrm{dm}^{-3}$, unless specified otherwise) of $\mathrm{Ca}^{2+}, \mathrm{Mg}^{2+}, \mathrm{Na}^{+}, \mathrm{P}\left(\mathrm{mg} \mathrm{dm}^{-3}\right)$, and $\mathrm{K}^{+}$of 1.32, $0.72,0.03,22 \mathrm{mg} \mathrm{dm}^{-3}$, and 0.22 , respectively, with an average $\mathrm{pH}=4.45$. In order to increase soil $\mathrm{pH}$, liming was performed by adding $86 \mathrm{~kg} \mathrm{ha}^{-1}$ of dolomitic limestone $(25 \%$ $\mathrm{Ca}$ and $17 \% \mathrm{Mg}$ ) with a $70 \%$ relative power of total neutralization, based on the method of exchangeable aluminium neutralization. Soil tillage was carried out after limestone was incorporated into a $0-20 \mathrm{~cm}$ soil layer, consisting of two crossed harrowings and a levelling harrow.

In the control treatment, plants were fertilized with an $\mathrm{N}-\mathrm{P}-\mathrm{K}$ formulation of 90-40-40 $\mathrm{kg} \mathrm{ha}^{-1}$, respectively, using urea $(45 \% \mathrm{~N})$, single superphosphate $\left(20 \% \mathrm{P}_{2} \mathrm{O}_{5}\right.$, $20 \% \mathrm{Ca}, 12 \% \mathrm{~S}, \mathrm{pH}<2.0)$, and potassium chloride $\left(60 \% \mathrm{~K}_{2} \mathrm{O}, 45 \% \mathrm{Cl}\right)$, according to crop recommendation by the state of Pernambuco, Brazil [28]. For this treatment, $50 \%$ of the $\mathrm{KCl}$ and urea were applied at planting, $25 \%$ as top-dressing (25 DAE), and the remaining $25 \%$ applied 20 days later. Phosphorus (P) was fully applied before planting. For the treatments combining TDS and $\mathrm{K}$ rates, neither $\mathrm{N}$ nor $\mathrm{P}$ fertilization was applied because the wastewater (TDS) already contained total $\mathrm{N}$ and total $\mathrm{P}$ in the concentrations of 126 and $13.7 \mathrm{mg} \mathrm{L}^{-1}$, respectively. Only potassium chloride $\left(60 \% \mathrm{~K}_{2} \mathrm{O}\right.$ and $\left.45 \% \mathrm{Cl}\right)$ was used in these treatments, distributed as $50 \%$ of the rate of each treatment at planting, $25 \%$ after thinning as top-dressing, and the remaining $25 \%$ applied 20 days later. The rates applied were $0,20,40,60$, and $80 \mathrm{~kg}$ of $\mathrm{K}_{2} \mathrm{O} \mathrm{ha}^{-1}$, which corresponded to $0,50,100,150$, and $200 \%$ of the recommended $\mathrm{K}$ fertilization rate for cotton, respectively.

For irrigated herbaceous cotton, the IPA (Agronomic Research Institute of the State of Pernambuco) [28] recommends, for an expected yield of $4000 \mathrm{~kg} \mathrm{ha}^{-1}$ (with a density of 70,000 to 80,000 plants ha $\left.{ }^{-1}\right)$, the potassium fertilization $\left(\mathrm{K}_{2} \mathrm{O}\right)$ of $40 \mathrm{~kg} \mathrm{ha}^{-1}$ when soil $\mathrm{K}^{+}$ concentration is between 0.12 and $0.23 \mathrm{cmol}_{\mathrm{c}} \mathrm{dm}^{-3}$. These concentrations correspond to 93.8 to $179.8 \mathrm{~kg} \mathrm{ha}^{-1}$ of $\mathrm{K}$, respectively. For $\mathrm{N}$, the IPA does not consider $\mathrm{N}$ levels, recommending $90 \mathrm{~kg} \mathrm{ha}^{-1}$. In the case of $\mathrm{P}$, when the levels of this element are approximately $20 \mathrm{mg} \mathrm{dm}^{-3}\left(40 \mathrm{~kg} \mathrm{ha}^{-1}\right)$, it is still recommended to apply $40 \mathrm{~kg} \mathrm{ha}^{-1}$ of $\mathrm{P}_{2} \mathrm{O}_{5}$. In the control treatment, phosphorus was fully applied before planting, and fertilization with $\mathrm{N}$ and $\mathrm{K}$ was divided three times over the cycle, as described above for $\mathrm{K}$ in the other treatments.

\subsection{Harvest and Analysed Variables}

Manual harvest started when $70 \%$ of the bolls were open (135 DAE) (Figure 1e). A second harvest was performed after the remaining bolls opened and the following parameters were determined: boll density (no. $\left.\mathrm{m}^{-2}\right)$, seed cotton yield $\left(\mathrm{kg} \mathrm{ha}^{-1}\right)$, lint yield $\left(\mathrm{kg} \mathrm{ha}^{-1}\right)$, and water use efficiency $\left(\mathrm{kg} \mathrm{m}^{-3}\right)$. Additionally, we estimated the fertilizer potassium use efficiency (FKUE, $\mathrm{kg} \mathrm{kg}^{-1}$ ) by relating the increase in seed cotton yield $\left(\mathrm{kg} \mathrm{ha}^{-1}\right)$ per unit of $\mathrm{K}_{2} \mathrm{O}$ applied $\left(\mathrm{kg} \mathrm{ha}^{-1}\right)$.

The data relative to the technological quality of the cotton fibre were obtained by sampling 20 bolls, randomly harvested, from the middle third of plants of the useful area of 
the plot [29]. The analysed variables were: fibre length (UHM, mm), fibre uniformity (UNF, $\%$ ), short fibre index (SFI, \%), and Micronaire index (MIC, $\mu \mathrm{g} \mathrm{pol}{ }^{-1}$ ). The UNF represents the homogeneity in fibre length. The SFI expresses the percentage of short fibres, and this value must be less than $10 \%$. The MIC reflects the fibre diameter, where the textile industry requires finer and longer fibres due to the process of modernization of textile machines. The technological variables were determined using the HVI (High Volume Instrument) fibre test system, model 900, from SpinLab/Zellweger Uster, belonging to the Fibre and Yarn Laboratory of EMBRAPA Cotton, Campina Grande, PB, Brazil.

\subsection{Data Analysis}

Analysis of variance by the Fisher's test at the probability level of 0.05 was performed to evaluate the effects of the irrigation regimes (IRs) with TDS and K rates (KRs) on the production components and fibre quality of coloured cotton, using the statistical package SAS 9.0 for Windows [30]. Multiple regression models (response surface methodology) were fitted to the means when the IR vs. KR interaction was significant. Polynomial regression models were fitted to the means when there were single significant effects of IR or KR.

\section{Results}

\subsection{Production Components and Yield}

The seed cotton yield and lint yield were significantly influenced by the TDS-IR and K rates, as well as by the interaction between both factors. The number of cotton bolls per area increased linearly with an increased irrigation depth but responded quadratically to the increase in the $\mathrm{K}$ rate, with the maximum number of bolls $\left(\sim 99 \mathrm{bolls}^{-2}\right)$ obtained with the irrigation regime of $150 \% E T_{C}$ combined with the estimated $\mathrm{K}$ rate of $96.3 \%$ of the recommendation for irrigated herbaceous cotton (Figure 3). The irrigation regime using treated domestic sewage to replace $100 \% E T_{C}$, and without $\mathrm{K}$ application, resulted in 77 bolls $\mathrm{m}^{-2}$, which was $45 \%$ higher than the average achieved by the control treatment, 53 bolls $\mathrm{m}^{-2}$.

The maximum physical yield of seed cotton $\left(3978 \mathrm{~kg} \mathrm{ha}^{-1}\right)$ was achieved with the irrigation regime of $150 \%$ of the $E T_{C}$ combined with the $\mathrm{K}$ rate of $84 \%$ of the recommendation for the crop (Figure 4). However, a KR higher than $84 \%$ of the recommendation led to a yield reduction when the same irrigation regime $\left(150 \%\right.$ of the $\left.E T_{C}\right)$ was maintained (Figure 4), suggesting that although cotton is relatively tolerant to salinity, the salt index (116.2) of $\mathrm{KCl}$ may have elevated the salinity of the soil beyond what was tolerated by cotton. The TDS irrigation regimes of 75 and $100 \%$ of the $E T_{C}$ replacement, without $\mathrm{K}$ application $(\mathrm{KR}=0 \%)$, resulted in seed cotton yields of 2771 and $3156 \mathrm{~kg} \mathrm{ha}^{-1}$, both higher than the yield observed for the control treatment $\left(2087 \mathrm{~kg} \mathrm{ha}^{-1}\right)$.

The evaluation of $\mathrm{K}$ rates resulted in a quadratic response for lint yield, with a maximum of $1380 \mathrm{~kg} \mathrm{ha}^{-1}$ obtained by the irrigation regimes of $150 \%$ of the $E T_{C}$, combined with a $\mathrm{K}$ rate of $77.9 \%$ of the crop recommendation (Figure 5). The application of irrigation regimes of 50,75 , and $100 \% E T_{C}$, without $\mathrm{K}$ fertilization, resulted in lint yields of 830 , $987 \mathrm{~kg} \mathrm{ha}^{-1}$, and $1112 \mathrm{~kg} \mathrm{ha}^{-1}$, with values similar or higher than the yield achieved by the control treatment $\left(812 \mathrm{~kg} \mathrm{ha}^{-1}\right)$.

\subsection{Water Use Efficiency}

The water deficit regime of $50 \% E T_{C}(307.75 \mathrm{~mm})$ combined with the $\mathrm{K}$ rate corresponding to $139 \%$ of the local recommendation led to a maximum water use efficiency $\left(0.99 \mathrm{~kg} \mathrm{~m}^{-3}\right)$ (Figure 6), about three times higher than the value observed in the control treatment $\left(0.34 \mathrm{~kg} \mathrm{~m}^{-3}\right)$. For irrigation regimes of 75 and $100 \%$ of the $E T_{C}$ with TDS, without $\mathrm{K}$ application, the WUE was 0.63 and $0.49 \mathrm{~kg} \mathrm{~m}^{-3}$, while the high irrigation regimes (125 and $150 \%$ of $E T_{C}$ ) showed the lowest values of WUE. 


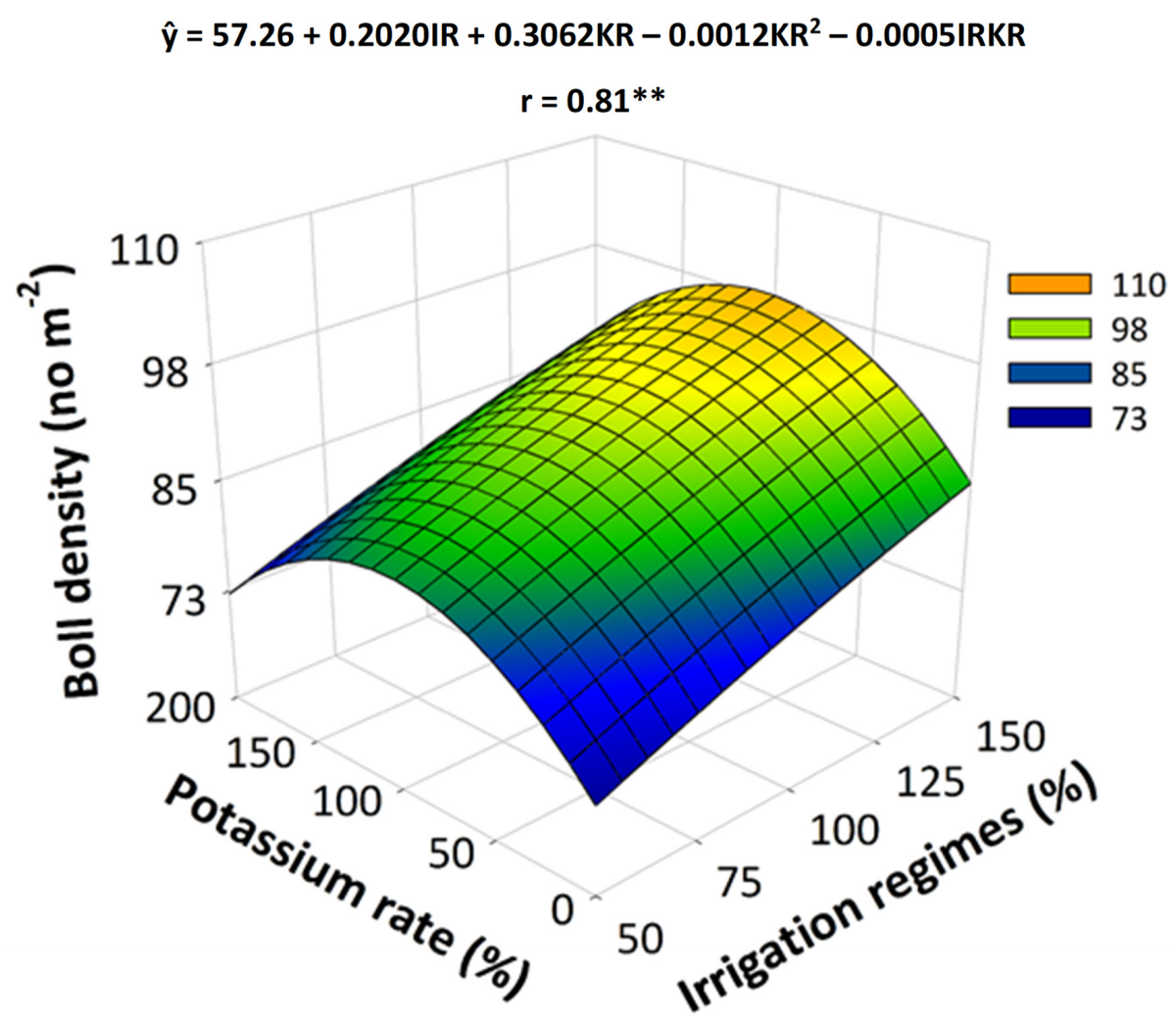

Figure 3. Response surface for the bolls density (no. $\mathrm{m}^{-2}$ ) of coloured cotton, cv. BRS Rubi, as a function of irrigation regimes with treated domestic sewage and potassium rates. The mean value for the control treatment (CT) was 53 bolls per $\mathrm{m}^{2}$. The correlation $(\mathrm{r})$ between boll density and both treatments had a significance level of 0.01 , represented by ${ }^{* *}$.

$\hat{y}=1017.17+29.39 I R+17.39 K R-0.08 I R^{2}-0.05 K R^{2}-0.06 I R K R$

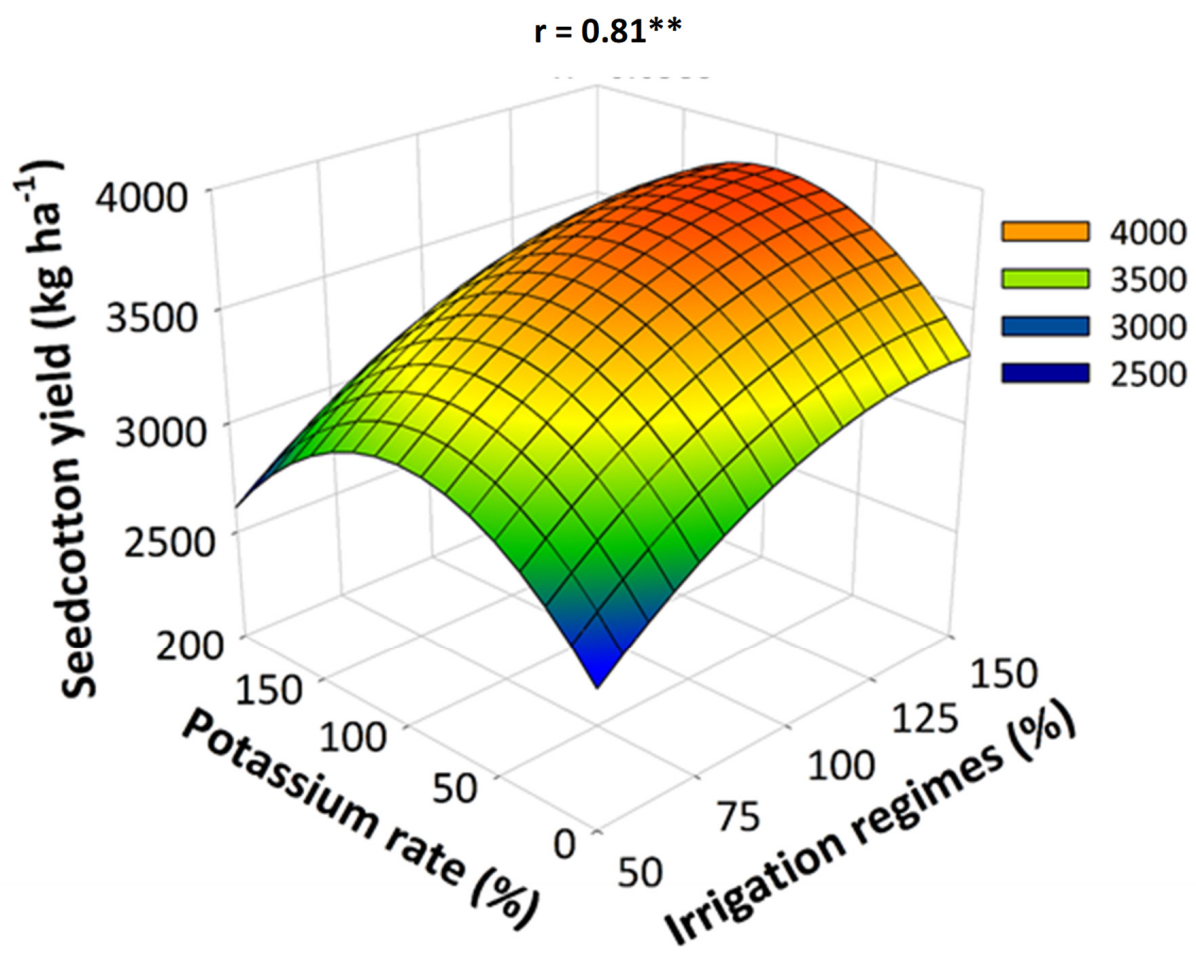

Figure 4. Response surface for seed cotton yield of coloured cotton, cv. BRS Rubi, as a function of irrigation regimes with treated domestic sewage and potassium rates. The mean value for the control treatment (CT) was $2087 \mathrm{~kg}$ ha ${ }^{-1}$. The correlation coefficient $(r)$ between seedcotton yield and both treatments had a significance level of 0.01 , represented by **. 


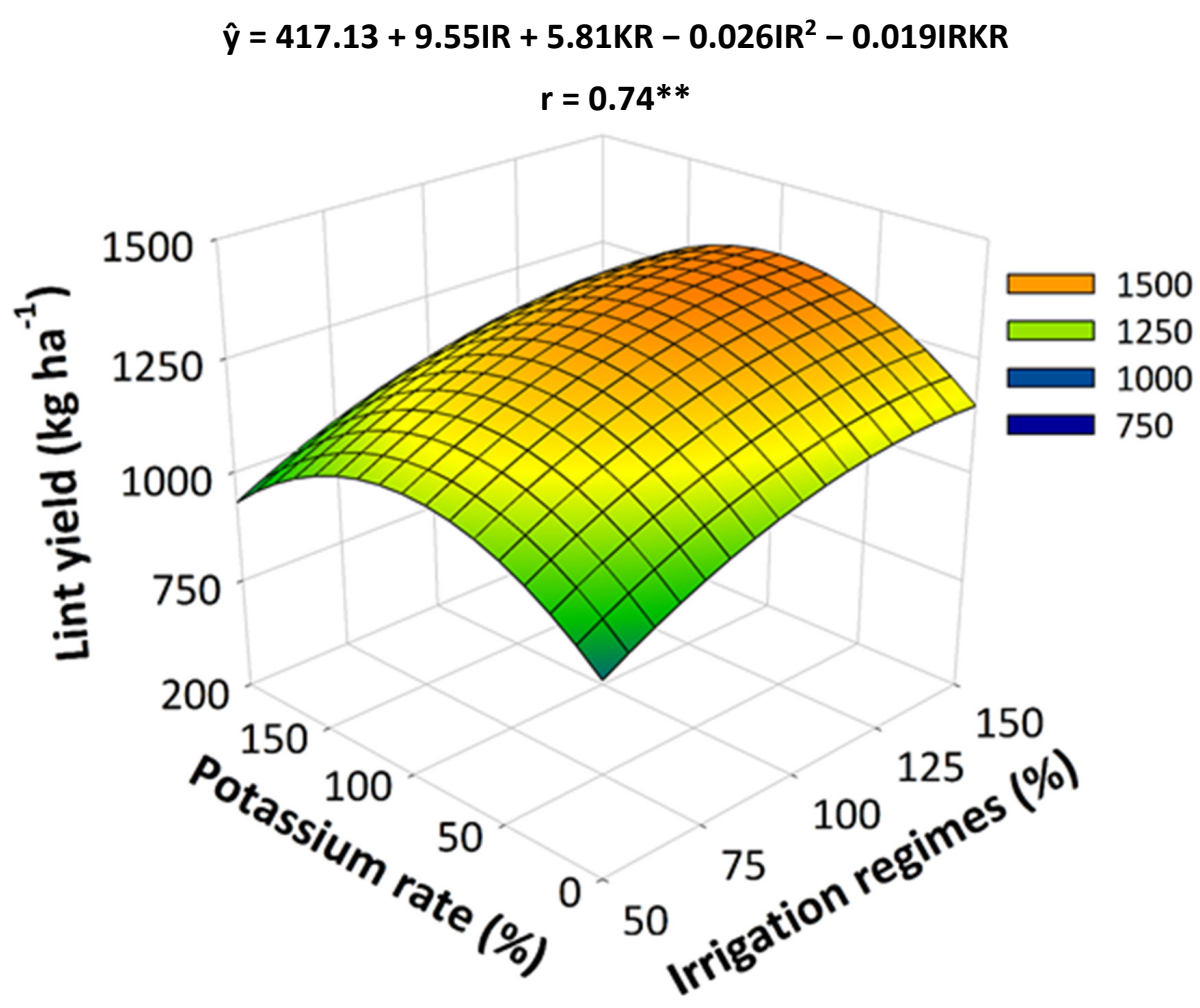

Figure 5. Response surface for lint yield of coloured cotton, cv. BRS Rubi, as a function of irrigation regimes with treated domestic sewage and potassium rates. The mean value for the control treatment (CT) was $812 \mathrm{~kg} \mathrm{ha}^{-1}$. The correlation coefficient ( $\mathrm{r}$ ) between lint yield and both treatments had a significance level of 0.01 , represented by ${ }^{* *}$.

$$
\hat{y}=1.38-0.0134 I R+0.0029 K R+0.000045 I R^{2}-0.000009 K R^{2}-0.000008 I R K R
$$

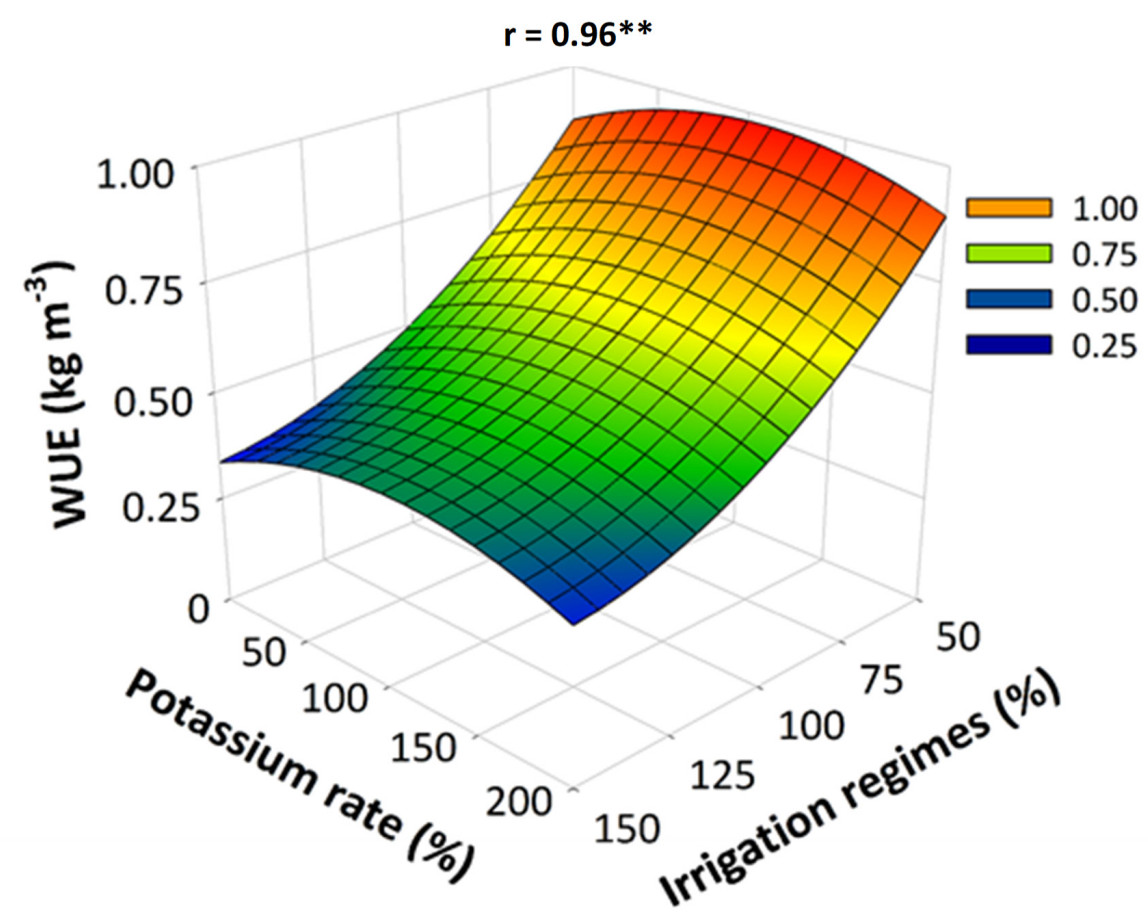

Figure 6. Response surface for water use efficiency (WUE) of coloured cotton, cv. BRS Rubi, as a function of irrigation regimes with treated domestic sewage and potassium rates. The mean value for the control treatment (CT) was $0.34 \mathrm{~kg} \mathrm{~m}^{-3}$. The correlation coefficient $(\mathrm{r})$ between WUE and both treatments $(\mathrm{r})$ had a significance level of 0.01 , represented by ${ }^{* *}$. 


\subsection{Fertilizer Potassium Use Efficiency}

The maximum fertilizer potassium use efficiency was $2.02 \mathrm{~kg} \mathrm{~kg}^{-1}$ for an irrigation regime with a TDS of $94.5 \% E T_{C}$ combined with the $\mathrm{K}$ dose of $97.6 \%$ of that recommended for cotton (Figure 7). For the irrigation regime of $75 \% E T_{C}$ combined with the same dose of $\mathrm{K}$, the FKUE value was $1.90 \mathrm{~kg} \mathrm{~kg}^{-1}$, only $6 \%$ lower than the maximum observed value. However, the FKUE values decreased in treatments with the smallest and largest irrigation regimes with TDS, regardless of the dose of potassium fertilizer applied.

\section{$\hat{y}=-3.595+0.0721 I R+0.0448 K R-0.000304 I R 2-0.000158 K R 2-0.000148 I R K R$}

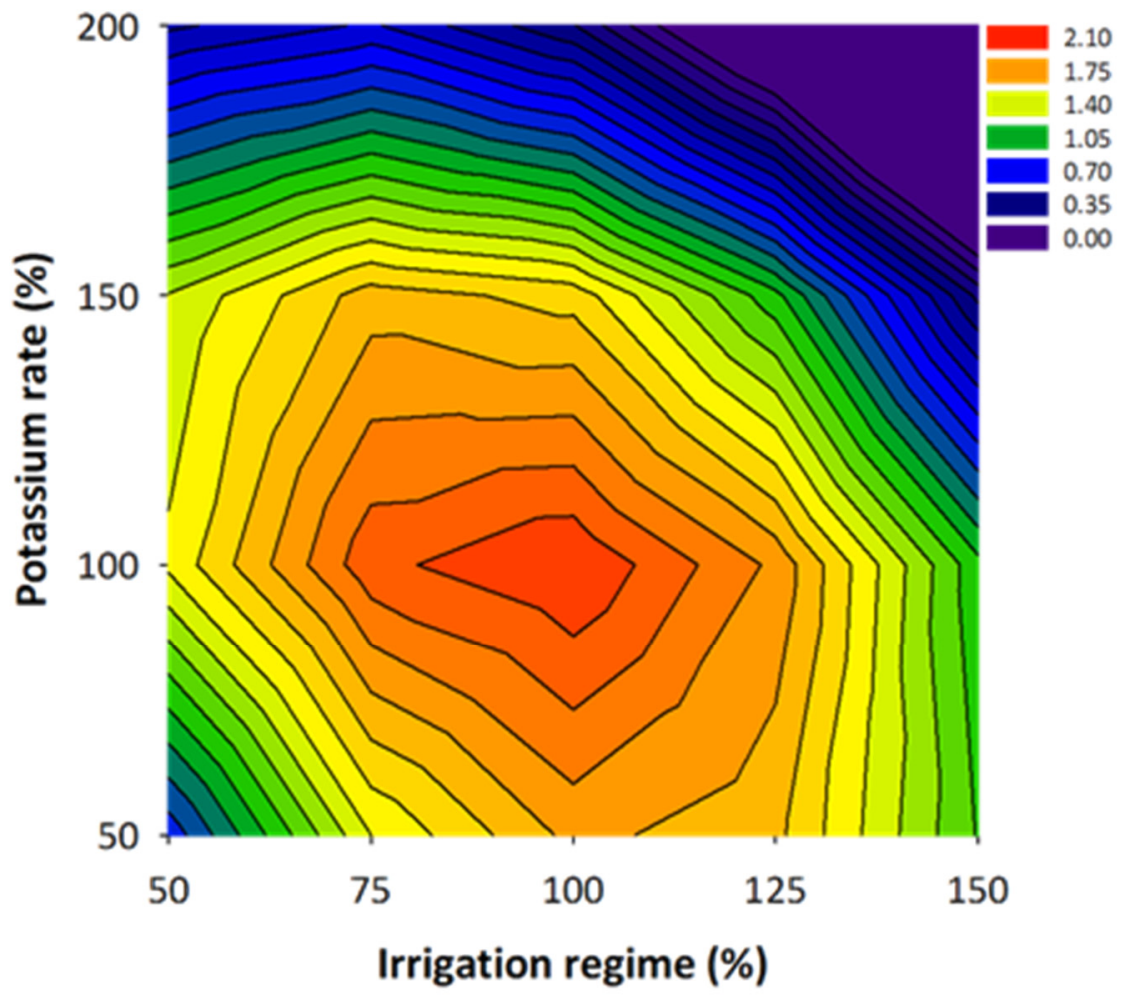

Figure 7. Potassium fertilizer use efficiency of coloured cotton, cv. BRS Rubi, as a function of irrigation regimes with treated domestic sewage and $\mathrm{K}$ rates.

\subsection{Fibre Technological Quality}

The effects of interaction were not significant for all variables of fibre quality $(p>0.05)$, and no isolated effects of water regime and $\mathrm{K}$ rates were observed for the fibre uniformity (UNF) and Micronaire index (MIC). The value of fibre uniformity ( $82 \%$ ) was the same for all treatments and $2.0 \%$ higher than the control ( $80 \%$ ) (Figure $8 \mathrm{a}$ ), while the mean value of MIC was $3.90 \mathrm{\mu g} \mathrm{pol}^{-1}$ for all combinations of water regimes and $\mathrm{K}$ rates (Figure $8 \mathrm{~b}$ ), and lower than that observed for control plants $\left(4.80 \mu \mathrm{g} \mathrm{pol}^{-1}\right)$. On the other hand, the irrigation regimes with treated domestic sewage (TDS) caused a significantly affected $(p<0.05)$ fibre length (UHM) and a short fibre index (SFI).

The fibre length (UHM) responded quadratically to the irrigation regime with TDS (Figure 8c), with a maximum length of $23.71 \mathrm{~mm}$ under an irrigation depth of $98.7 \%$ of the $E T_{C}$, but higher irrigation regimes reduced the fibre length. The TDS irrigation regime that resulted in the maximum UHM was lower than $100 \%$ of the $E T_{C}$ and was $4 \%$ higher than that obtained from control plants $(22.78 \mathrm{~mm})$. Differently, the short fibre index (SFI) increased linearly as a function of the increase in water availability with TDS. However, the means observed for each irrigation regime with TDS did not differ from those observed for control plants (Figure 8d). 

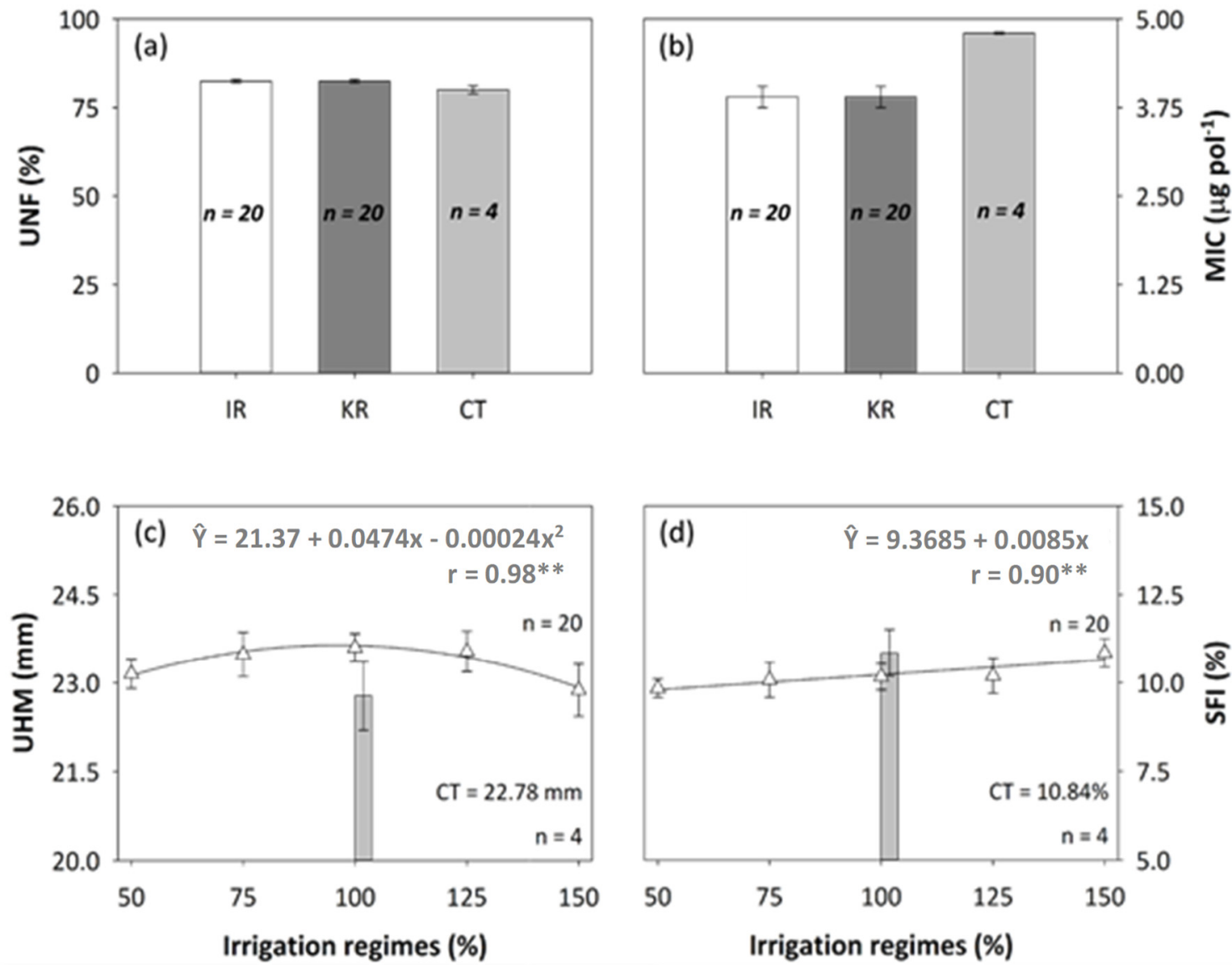

Figure 8. Uniformity-UNF (a); micronaire index-MIC (b); length-UHM (c); short fibre index-SFI (d) of the fibres of coloured cotton, cv. BRS Rubi, as a function of irrigation regimes with treated domestic sewage and potassium rates. Vertical bars indicate the mean \pm standard error. The number of samples used to originate each data point is represented by $n$. The correlation coefficient $(\mathrm{r})$ had a level of significance of 0.01 , represented by ${ }^{* *}$.

\section{Discussion}

TDS and deficit irrigation are crucial alternatives to optimize the production of irrigated coloured cotton in semiarid tropical regions, saving water and fertilizers, and leading to a more sustainable irrigated agriculture [31-33]. Our results showed that the use of TDS in a full irrigation regime $\left(100 \% E T_{C}\right)$ and at a deficit irrigation regime $\left(75 \% E T_{C}\right)$, even without $\mathrm{K}$ fertilization, increased seed cotton productivity by 51 and $32 \%$, and the lint cotton yield by 37 and $21 \%$, respectively (Figures 4 and 5), compared to the control treatment $\left(100 \% E T_{C}\right.$ with freshwater plus mineral fertilization). The higher availability of TDS in the soil probably allowed for greater absorption of water and nutrients by the roots, promoting better photosynthetic efficiency and increased crop yield [32,34,35]. It is important to emphasize that the application of fertilizers with nitrogen and phosphorus was carried out only in the control treatment as TDS water already contained 126 and $13.7 \mathrm{mg} \mathrm{L}^{-1}$ of total $\mathrm{N}$ and total $\mathrm{P}$, respectively, further evidencing the beneficial effect of cotton irrigation with TDS, which had 1.4-fold more $\mathrm{Ca}^{+2}, 5$-fold more $\mathrm{Mg}^{+2}$, 4-fold more $\mathrm{K}^{+}$, and $2 \mathrm{mmol}_{\mathrm{c}} \mathrm{L}^{-1}$ of $\mathrm{NO}_{3}{ }^{-}$more than freshwater [23,35].

The highest values of seed cotton and lint yield were obtained with the highest TDS depth $\left(150 \% E T_{C}\right)$, but this treatment showed a low water use efficiency $(0.38)$, a value similar to that observed in the control treatment $\left(0.34 \mathrm{~kg} \mathrm{~m}^{-3}\right)$, and low values of fertilizer potassium use efficiency (FKUE). This reduction in FKUE in this treatment can be explained, at least in part, by the increase in $\mathrm{K}$ loss by leaching associated with excess water in the soil profile [36]. On the contrary, for irrigation regimes of 75 and $100 \%$ of the $E T_{C}$ with TDS, and without K application, the WUE was $84 \%$ and $44 \%$ higher than in control 
plants, respectively. These treatments with TDS also showed high values of potassium use efficiency. These results corroborate those obtained by [29,37], who reported that although higher water availability promoted a higher yield of herbaceous cotton, it leads to a lower water use efficiency. According to [38], some factors may influence water use efficiency, such as the increased vegetative/reproductive structures ratio and, consequently, increased losses through evapotranspiration.

Potassium rates (KR) above $84 \%$ of the recommendation for cotton resulted in a decreased yield when the TDS irrigation regime was maintained at $150 \%$ of the $E T_{C}$. On the other hand, for the treatments of deficit irrigation $\left(75 \%\right.$ of $\left.E T_{C}\right)$ and full irrigation with TDS, the optimal K rates were 129 and $114 \%$ of that recommended for the crop, with yields of 3602 and $3804 \mathrm{~kg} \mathrm{ha}^{-1}$ of seed cotton, respectively. These values of crop yield were 72 and $82 \%$ higher than those observed in the control treatment. For the maximum lint yield, when maintaining the same irrigation regimes (75 and $100 \%$ of the $E T_{C}$ with TDS), the optimal levels of K were 115 and $103 \%$ of the recommendation for the irrigated herbaceous cotton in the Brazilian semiarid climate, obtaining yields 1240 and $1313 \mathrm{~kg} \mathrm{ha}^{-1}$, respectively. Similar results were observed for WUE, for both deficit and full irrigation treatments, showing values 126 and $79 \%$ higher than those of the control treatment, when $\mathrm{K}$ recommendations were 128 and $117 \%$, respectively. The irrigation regimes using TDS provided a daily application of $\mathrm{K}$ at $1.12 \mathrm{mmol}_{\mathrm{C}} \mathrm{L}^{-1}$ throughout the different stages of crop development, which probably led to a more efficient $\mathrm{K}$ absorption by cotton plants than the scattered application of a slow-release mineral fertilizer applied in the control treatment. However, our results suggest that an increase of 15 and 30\% in the KR can promote an increase in the seed cotton yield and water use efficiency of cotton, even under deficit irrigation with TDS. These results were consistent with a recent report that three cultivars of Bt cotton produced higher seed cotton yields when extra $\mathrm{K}$ fertilization was provided under deficit irrigation, mainly for the early maturing cultivar [19].

In a work evaluating the split application of potassium fertilizer, it was found [36] that one half of the $\mathrm{K}$ fertilization applied at pre-planting and one half at peak flowering improved the agronomic yield of cotton and the efficiency in the absorption of $\mathrm{K}$. Based on our results, the peak of flowering was where there was the greatest water demand for the crop, with the highest application of TDS in this period and the highest deposition of $\mathrm{K}$ to the soil. Certainly, the K concentration found in TDS $\left(1.12 \mathrm{mmol}_{\mathrm{c}} \mathrm{L}^{-1}\right)$ was not enough to meet the maximum demand of the crop, which justified the application of mineral fertilizer (including K) to obtain a high productivity, mainly under deficit irrigation when the flow of $\mathrm{K}$ into the plant was reduced due to the reduced water availability. It is important to note that the recommended dose of $\mathrm{K}$ for the semiarid region of Brazil is relatively low, compared to that used in other cotton-producing regions worldwide [39-41]. Thus, the mentioned increases of 15 to $30 \%$ in $\mathrm{K}$ doses for treatments with either deficit or full irrigation resulted in doses not exceeding $60 \mathrm{~kg} \mathrm{ha}^{-1}$ of $\mathrm{K}_{2} \mathrm{O}$.

Our analyses indicated that there was a lower impact of TDS application and K rates on fibre technological quality than those observed for yield and water use efficiency. Although $\mathrm{K}$ fertilizers did not appear to be limiting to fibre quality, water deficit, or water excess with TDS affected the fibre length and short fibre index. The increment in UHM caused by the increase in water replacement up to $98.7 \%$ of the $E T_{C}$ (Figure $8 \mathrm{c}$ ) indicated that the soil could be enriched with various nutrients, including $\mathrm{K}$, through the use of TDS as irrigation water $[18,42,43]$. In our study, this raised soil fertility of more $\mathrm{Mg}^{+2}, \mathrm{~K}^{+}$, and $\mathrm{NO}_{3}{ }^{-}$provided by the TDS water possibly favoured cell development and, consequently, a greater fibre elongation, in agreement with what was previously discussed by others $[1,35]$.

Fibre formation in cotton is the result of several biological processes initiated shortly after flowering. Water deficit after flowering and during the fibre elongation stage can compromise the fibre length because the physiological and mechanical processes of cell elongation are hindered by a water shortage [44,45]. Despite the negative effect, in irrigation regimes of 50 and $75 \%$ of the $E T_{C}$ with TDS, the fibre lengths were equal to 23.13 and $23.57 \mathrm{~mm}$, respectively, both longer than achieved by control plants $(22.78 \mathrm{~mm})$. Nev- 
ertheless, the use of TDS to irrigate coloured cotton promoted average values of UHM within the industrial standard required for the cultivar BRS Rubi. On the other hand, the negative effect caused by water excess on the fibre length can be explained, at least in part, by changes in carbon partitioning in the whole plant.

The minimum standards of fibre quality for the textile industry in Brazil require lower percentages of short fibres $(<9 \%)$, with lower values of the short fibre index (SFI) indicating a better cotton fibre quality. The application of irrigation regimes with TDS in the cultivation of the 'BRS Rubi' cotton resulted in SFI varying from 9.8 to $10.6 \%$; hence, classified as medium quality, with a lower and more adequate value of SFI observed under deficit irrigation with TDS. The irrigation regimes with TDS and KR also did not alter the cotton fibre uniformity from values observed under the control treatment. The lack of significant effect of KR or TDS on fibre uniformity was also observed by $[44,46,47]$.

Another important characteristic of the textile industry is the requirement of increasingly finer fibres. A micronaire index (MIC) from 3.5 to $4.2 \mu \mathrm{g} \mathrm{pol}^{-1}$ allows fibres to be spun by high-speed rotors in modern spinning equipment. According to industry classification, the MIC values ( $\mu \mathrm{g} \mathrm{pol}^{-1}$ ) can be included in the following categories: <3.0 (very fine); 3.0-3.9 (fine); 4.0-4.9 (medium); 5.0-5.9 (coarse); >6 (very coarse) [48]. The results obtained in this study were consistent with the standards required by the textile industry, and treatment with TDS, regardless of the regime adopted, proved to be sufficient to promote the development of finer fibres, presenting a MIC of $3.9 \mu \mathrm{g} \mathrm{pol}{ }^{-1}$, about $19 \%$ lower than MIC values observed for the control treatment. The authors of [43] reported that finer fibres resulted from the cultivation of cotton with treated wastewater; thus, corroborating the findings of our study.

Although the irrigation regime of $50 \%$ of the crop requirement resulted in a moderate reduction in yield, [44] reported that no negative effects on the technological quality of cotton fibres occurred under the semiarid conditions of Greece. More recent findings indicate that deficit irrigation regimes in consecutive crops can reduce the quality of the fibres, making them shorter and coarser. In general, these effects are stronger during the stage of fibre elongation and development, which can reduce fibre growth and increase fibre thickness [45]. However, no negative effect of deficit irrigation with TDS on fibre quality was observed in the present study, showing better results than those observed for the control treatment (Figure 8b).

Since longer and finer fibres were found in the treatments subjected to irrigation regimes with TDS, compared to the control treatment, it is inferred that the conventional management of $\mathrm{K}$ fertilization and irrigation with fresh water may not be adequate to obtain coloured cotton fibres with better intrinsic characteristics in the tropical semiarid region. In contrast, the management with TDS allowed a higher yield and water use efficiency, as well as an adequate fibre quality. Additionally, deficit irrigation regimes with TDS can be an essential strategy to increase water use efficiency for semiarid regions [45] without compromising the technological characteristics of the cotton fibre.

\section{Conclusions}

Our results suggested that irrigation with treated domestic sewage, when associated with $\mathrm{K}$ application, can be successfully used in the production of coloured cotton, leading to better results than conventional cultivation with freshwater, which requires complete mineral fertilization. The best high crop yield, water use efficiency, and potassium use efficiency were obtained for treatments with TDS at both deficit and full irrigation (75 and $100 \% E T_{C}$ ) when combined with moderate increases in the recommended $\mathrm{K}$ rates. In addition, no negative effect of either deficit or full irrigation with TDS was observed on cotton fibre quality. The treatments of $75 \%$ and $100 \%$ ETc gave a better or similar fibre quality (meeting or exceeding the fibre quality requirements of the textile industry) when compared with freshwater plus mineral fertilization or with a TDS application above $100 \%$ $E T_{C}$. Therefore, moderate deficit irrigation with TDS is proposed as an important strategy to promote the partial recycling of nutrients, decreasing the crop fertilizer input, and having 
the potential to increase profit margins for cotton production in tropical semiarid regions worldwide.

Author Contributions: Conceptualization, B.L.C.L. and Ê.F.F.S.; methodology, B.L.C.L. and Ê.F.F.S.; software, B.L.C.L., formal analysis, B.L.C.L.; resources, Ê.F.F.S., J.H.Z. and C.P.C.T.N.; data curation, B.L.C.L. and E.F.F.S.; statistical expertise, B.L.C.L. and Ê.F.F.S.; writing—original draft preparation, B.L.C.L.; writing-review and editing, Ê.F.F.S., J.F.S.F., C.F.L. and F.J.R.C.; visualization, Ê.F.F.S., supervision, Ê.F.F.S., project administration, Ê.F.F.S., funding acquisition, Ê.F.F.S. All authors have read and agreed to the published version of the manuscript.

Funding: This research was funded by the National Council for Scientific and Technological Development, grant number 403519/2013-6, CNPq, Brasília, Brazil.

Institutional Review Board Statement: Not applicable as this study did not involve human or animal subjects.

Informed Consent Statement: Not applicable as this study did not involve human or animal subjects.

Data Availability Statement: The data that supporting the findings of this study are available from the corresponding authors upon reasonable request.

Acknowledgments: Our thanks to the Pernambuco State Science and Technology Support Foundation (FACEPE) for the scholarship granted to the first author, to the Brazilian Agricultural Research Corporation (EMBRAPA Cotton) in Campina Grande, PB, Brazil, for the technical analysis of the coloured cotton fibre and the National Council for Scientific and Technological Development (CNPq) for the financial support for the research project (process number 403519/2013-6).

Conflicts of Interest: The authors declare no conflict of interest.

\section{References}

1. Guo, K.; Tu, L.; He, Y.; Deng, J.; Wang, M.; Huang, H.; Li, Z.; Zhang, X. Interaction Between Calcium and Potassium Modulates Elongation Rate in Cotton Fiber Cells. J. Exp. Bot. 2017, 68, 5161-5175. [CrossRef] [PubMed]

2. Zhang, J.; Abdelraheem, A.; Wedegaertner, T. Genetic Variation of Waterlogging Tolerance in Pima (Gossypium barbadense) Cotton and Glanded and Glandless Upland Cotton (Gossypium hirsutum) under Field Conditions. Ind. Crops Prod. 2019, 129, 169-174. [CrossRef]

3. Abdelraheem, A.; Esmaeili, N.; O'Connell, M.; Zhang, J. Progress and Perspective on Drought and Salt Stress Tolerance in Cotton. Ind. Crops Prod. 2019, 130, 118-129. [CrossRef]

4. ABRAPA. Algodão no Mundo. Available online: http://www.abrapa.com.br/Paginas/dados/algodao-no-mundo.aspx (accessed on 3 April 2018).

5. Ayele, A.; Hequet, E.; Kelly, B. The Impact of Fiber Maturity on Estimating the Number of Cotton (Gossypium hirsutum L.) Fibers per Seed Surface Area. Ind. Crops Prod. 2017, 102, 16-22. [CrossRef]

6. Nascimento, P.S.; Alves, L.S.; Paz, V.P.S. Performance of Colored Cotton under Irrigation Water Salinity and Organic Matter Dosages. Rev. Ambient. Agua 2019, 14, e2369. [CrossRef]

7. Ozturk, E.; Koseoglu, H.; Karaboyaci, M.; Yigit, N.O.; Yetis, U.; Kitis, M. Minimization of Water and Chemical Use in a Cotton/Polyester Fabric Dyeing Textile Mill. J. Clean. Prod. 2016, 130, 92-102. [CrossRef]

8. Carvalho, L.P.; Barroso, P.A.V.; Dos Santos, J.A.T.; Alves, H.S. Seleção Massal e Porcentagem de Fibra em Cultivar de Algodoeiro Colorido. Pesqui. Agropecu. Bras. 2005, 40, 895-898. [CrossRef]

9. Juhasz, A.C.P.; Condé, A.B.T.; Rabelo, H.O.; Pimenta, S.; Soares, B.O. Genetic Variability of White and Colored Cotton in Order to Improve the Fiber Quality in North of Minas Gerais. Rev. Agrar. 2013, 6, 368-375.

10. Brenot, A.; Ramchandani, M.; Lemoine, L.; Tornaire, C.; Deroche, M.; Godat, E.; Coste-Manière, I.; Sette, E.; Chuffart, C. Water Footprint in Fashion and Luxury Industry. In Water in Textiles and Fashion; Muthu, S.S., Ed.; Elsevier Ltd.: Kidlington, UK, 2019; pp. 95-113. ISBN 9780081026335.

11. Mekonnen, M.M.; Hoekstra, A.Y. The Green, Blue and Grey Water Footprint of Crops and Derived Crop Products. Hydrol. Earth Syst. Sci. 2011, 15, 1577-1600. [CrossRef]

12. Chen, L.; Wang, L.; Wu, X.; Ding, X. A Process-Level Water Conservation and Pollution Control Performance Evaluation Tool of Cleaner Production Technology in Textile Industry. J. Clean. Prod. 2017, 143, 1137-1143. [CrossRef]

13. Salgot, M.; Folch, M. Wastewater Treatment and Water Reuse. Curr. Opin. Environ. Sci. Health 2018, 2, 64-74. [CrossRef]

14. Jasechko, S.; Perrone, D. Global Groundwater Wells at Risk of Running dry. Science 2021, 372, 418-421. [CrossRef]

15. Qadir, M.; Drechsel, P.; Jiménez Cisneros, B.; Kim, Y.; Pramanik, A.; Mehta, P.; Olaniyan, O. Global and Regional Potential of Wastewater as a Water, Nutrient and Energy Source. Nat. Resour. Forum 2020, 44, 40-51. [CrossRef] 
16. Simões, K.S.; Peixoto, M.F.S.P.; Almeida, A.T.; Ledo, C.A.S.; Peixoto, C.P.; Pereira, F.A.C. Água Residuária de Esgoto Doméstico Tratado na Atividade Microbiana do Solo e Crescimento da Mamoneira. Rev. Bras. Eng. Agríc. Ambient. 2013, 17, 518-523. [CrossRef]

17. Alves, W.W.A.; Azevedo, C.A.V.; Batista, R.C.; Neto, J.D.; de Macêdo Beltrão, N.E. Effect of Treated Wastewater, Nitrogen and Phosphorus on Quality of the Brown Fiber Cotton. In Proceedings of the 2006 ASAE Annual Meeting, Portland, OR, USA, 9-12 July 2006; American Society of Agricultural and Biological Engineers: St. Joseph, MI, USA, 2006.

18. Alikhasi, M.; Kouchakzadeh, M.; Baniani, E. The Effect of Treated Municipal Wastewater Irrigation in Non-Agricultural Soil on Cotton Plant. J. Agric. Sci. Technol. 2012, 14, 1357-1364.

19. Uzen, N.; Cetin, O.; Unlu, M. Effects of Domestic Wastewater Treated by Anaerobic Stabilization on Soil Pollution, Plant Nutrition, and Cotton Crop Yield. Environ. Monit. Assess. 2016, 188, 664. [CrossRef] [PubMed]

20. Tariq, M.; Afzal, M.N.; Muhammad, D.; Ahmad, S.; Shahzad, A.N.; Kiran, A.; Wakeel, A. Relationship of Tissue Potassium Content with Yield and Fiber Quality Components of Bt Cotton as Influenced by Potassium Application Methods. Field Crop. Res. 2018, 229, 37-43. [CrossRef]

21. Alvares, C.A.; Stape, J.L.; Sentelhas, P.C.; Moraes Gonçalves, J.L.; Sparovek, G. Köppen's Climate Classification Map for Brazil. Meteorol. Z. 2013, 22, 711-728. [CrossRef]

22. FAO. IUSS-WRB International Soil Classification System for Naming Soils and Creating Legends for Soil Maps; FAO: Rome, Italy, 2014; Volume World Soil, ISBN 9251055114.

23. Lima, B.L.C.; Silva, Ê.F.F.; Bezerra, J.R.C.; Silva, G.F.; Cruz, F.J.R.; Santos, P.R.; Campeche, L.F.S.M. Agronomic Performance of Colored Cotton Influenced by Irrigation with Treated Domestic Sewage and Potassium Fertilization in Semi-Arid Region of Brazil. DYNA 2019, 86, 74-80. [CrossRef]

24. APHA. Standard Methods for Examination of Water and Wastewater, 22nd ed.; American Public Health Association: Washington, DC, USA, 2012.

25. Allen, R.G.; Pereira, L.S.; Raes, D.; Smith, M. Crop Evapotranspiration: Guidelines for Computing Crop Water Requirements; FAO: Rome, Italy, 1998.

26. Bezerra, J.R.C.; De Azevedo, P.V.; Da Silva, B.B.; Dias, J.M. Evapotranspiração e Coeficiente de Cultivo do Algodoeiro BRS-200 Marrom, irrigado. Rev. Bras. Eng. Agríc. Ambient. 2010, 14, 625-632. [CrossRef]

27. Keller, J.; Bliesner, R.D. Sprinkle and Trickle Irrigation; Van Nostrand Reinhold: New York, NY, USA, 1990.

28. IPA. Recomendações de adubação para o Estado de Pernambuco, 3rd ed.; Instituto Agronômico de Pernambuco: Recife, Brazil, 2008.

29. Zonta, J.H.; Bezerra, J.R.C.; Sofiatti, V.; Farias, F.J.C.; Carvalho, L.P. Efeito da Irrigação no Rendimento e Qualidade de Fibras em Cultivares de Algodoeiro Herbáceo. Rev. Caatinga 2015, 28, 43-52. [CrossRef]

30. SAS. In System for Windows 2002; SAS Institute Inc.: Cary, NC, USA, 2002.

31. Yang, C.; Luo, Y.; Sun, L.; Wu, N. Effect of Deficit Irrigation on the Growth, Water Use Characteristics and Yield of Cotton in Arid Northwest China. Pedosphere 2015, 25, 910-924. [CrossRef]

32. Zonta, J.H.; Bezerra, J.R.C.; Sofiatti, V.; Brandão, Z.N. Yield of Cotton Cultivars under Different Irrigation Depths in the Brazilian Semi-Arid Region. Rev. Bras. Eng. Agríc. Ambient. 2015, 19, 748-754. [CrossRef]

33. Gonçalves, I.Z.; Barbosa, E.A.A.; Santos, L.N.S.; Nazario, A.A.; Feitosa, D.R.C.; Tuta, N.F.; Matsura, E.E. Nutritional balance and Production of Sugarcane Irrigated with Treated Wastewater through Subsurface Drip. Irrig. Sci. 2019, 37, 207-217. [CrossRef]

34. Cetin, O.; Bilgel, L. Effects of Different Irrigation Methods on Shedding and Yield of Cotton. Agric. Water Manag. 2002, 54, 1-15. [CrossRef]

35. Lima, B.L.C.; Silva, Ê.F.F.; Santos, H.R.B.; Souza, E.R. Potassium Fertilization and Irrigation with Treated Wastewater on Gas Exchange of Colored Cotton. Rev. Bras. Eng. Agrícola Ambient. 2018, 22, 741-746. [CrossRef]

36. Yang, F.Q.; Du, M.W.; Tian, X.L.; Eneji, A.E.; Li, Z.H. Cotton Yield and Potassium Use Efficiency as Affected by Potassium Fertilizer Management with Stalks Returned to Field. Crop. Sci. 2016, 56, 740-746. [CrossRef]

37. Dağdelen, N.; Başal, H.; Yılmaz, E.; Gürbüz, T.; Akçay, S. Different Drip Irrigation Regimes Affect Cotton Yield, Water Use Efficiency and Fiber Quality in Western Turkey. Agric. Water Manag. 2009, 96, 111-120. [CrossRef]

38. Karam, F.; Lahoud, R.; Masaad, R.; Daccache, A.; Mounzer, O.; Rouphael, Y. Water Use and Lint Yield Response of Drip Irrigated Cotton to the Length of Irrigation Season. Agric. Water Manag. 2006, 85, 287-295. [CrossRef]

39. Kaneko, F.H.; Leal, A.J.F.; Dias, A.R.; Anselmo, J.L.; Buzetti, S.; Bem, E.A.D.; de Gitti, D.C.; Nascimento, V. Resposta do Algodoeiro em Cultivo Adensado a Doses de Nitrogênio, Fósforo e Potássio. Rev. Agrar. 2014, 7, 382-389.

40. Hu, W.; Jiang, N.; Yang, J.; Meng, Y.; Wang, Y.; Chen, B.; Zhao, W.; Oosterhuis, D.M.; Zhou, Z. Potassium (K) Supply Affects K Accumulation and Photosynthetic Physiology in Two Cotton (Gossypium hirsutum L.) Cultivars with Different K Sensitivities. Field Crop. Res. 2016, 196, 51-63. [CrossRef]

41. Chen, J.; Guo, Z.; Chen, H.; Yang, X.; Geng, J. Effects of Different Potassium Fertilizer Types and Dosages on Cotton Yield, Soil Available Potassium and Leaf Photosynthesis. Arch. Agron. Soil Sci. 2020, 67, 275-287. [CrossRef]

42. Azevedo, M.R.D.Q.A.; König, A.; Beltrão, N.E.D.M. Características Tecnológicas da Fibra do Algodão Herbáceo sob Efeito de Adubação Nitrogenada e Irrigação com Água Residuária Tratada Acteristics o. Rev. Bras. Eng. Agric. Ambient. 2005, 9, 202-206. [CrossRef]

43. Dos Santos, S.R.; Soares, A.A.; Kondo, M.K.; Matos, A.T.; Maia, V.M. Indicadores de Produção e Qualidade da Fibra do Algodoeiro Fertirrigado com Água Residuária Sanitária. Eng. Agríc. 2016, 36, 525-536. [CrossRef] 
44. Papastylianou, P.T.; Argyrokastritis, I.G. Effect of Limited Drip Irrigation Regime on Yield, Yield Components, and Fiber Quality of Cotton under Mediterranean Conditions. Agric. Water Manag. 2014, 142, 127-134. [CrossRef]

45. Zhang, D.; Luo, Z.; Liu, S.; Li, W.; Tang, W.; Dong, H. Effects of Deficit Irrigation and Plant Density on the Growth, Yield and Fiber Quality of Irrigated Cotton. Field Crop. Res. 2016, 197, 1-9. [CrossRef]

46. Freitas, R.J.; Leandro, W.M.; Carvalho, M.C.S. Efeito da Adubação Potássica via solo e Foliar Sobre a Produção e a Qualidade da Fibra em Algodoeiro (Gossypium hirsutum L.). Pesqui. Agropecuária Trop. 2007, 37, 106-112.

47. Tsialtas, I.T.; Shabala, S.; Baxevanos, D.; Matsi, T. Effect of Potassium Fertilization on Leaf Physiology, Fiber Yield and Quality in Cotton (Gossypium hirsutum L.) under Irrigated Mediterranean Conditions. Field Crop. Res. 2016, 193, 94-103. [CrossRef]

48. Santana, J.C.F.; Wanderley, M.J.R.; Beltrão, N.E.M.; Azevedo, D.M.P.; Leão, A.B.; Vieira, D.J. Características da Fibra e do Fio do Algodão. In O Agronegócio do Algodão no Brasil; Beltrão, N.E.M., Azevedo, D.M.P., Eds.; Embrapa Informação Tecnológica: Brasília, Brazil, 2008; pp. 1099-1120. 